Sabine De Knop and Gaëtanelle Gilquin (Eds.)

Applied Construction Grammar 


\section{Applications of Cognitive Linguistics}

Editors

Gitte Kristiansen

Francisco J. Ruiz de Mendoza Ibáñez

Honorary editor

René Dirven

\section{Volume 32}




\section{Applied Construction Grammar}

Edited by

Sabine De Knop

Gaëtanelle Gilquin

DE GRUYTER

MOUTON 
ISBN 978-3-11-045421-5

e-ISBN (pdf) 978-3-11-045826-8

e-ISBN (EPUB) 978-3-11-045618-9

ISSN 1861-4078

\section{Library of Congress Cataloging-in-Publication Data}

A CIP catalog record for this book has been applied for at the Library of Congress.

\section{Bibliographic information published by the Deutsche Nationalbibliothek}

The Deutsche Nationalbibliothek lists this publication in the Deutsche Nationalbibliografie; detailed bibliographic data are available on the Internet at http://dnb.dnb.de.

(C) 2016 Walter de Gruyter GmbH, Berlin/Boston

Typesetting: RoyalStandard, Hong Kong

Printing and binding: $\mathrm{CPI}$ books $\mathrm{GmbH}$, Leck

(2) Printed on acid-free paper

Printed in Germany

www.degruyter.com 


\section{Table of contents}

List of contributors - vii

\section{Introduction}

Gaëtanelle Gilquin and Sabine De Knop

Exploring L2 constructionist approaches - 3

\section{Constructionist approaches to L2 learning and teaching}

Thomas Herbst

Foreign language learning is construction learning - what else?

Moving towards Pedagogical Construction Grammar -21

Sabine De Knop and Fabio Mollica

A construction-based analysis of German ditransitive phraseologisms for language pedagogy -53

Minchang Sung and Hyun-Kwon Yang

Effects of construction-centered instruction on Korean students' learning of English transitive resultative constructions -89

Gaëtanelle Gilquin

Input-dependent L2 acquisition: Causative constructions in English as a foreign and second language -115

\section{Crosslinguistic applications of constructionist approaches}

Francisco José Ruiz de Mendoza Ibáñez and María del Pilar Agustín Llach Cognitive Pedagogical Grammar and meaning construction in L2 - 151

Alberto Hijazo-Gascón, Teresa Cadierno and Iraide Ibarretxe-Antuñano Learning the placement caused motion construction in L2 Spanish — 185

Annalisa Baicchi

The role of syntax and semantics in constructional priming: Experimental evidence from Italian university learners of English through a sentenceelicitation task 211 
vi Table of contents

Paolo Della Putta

Do we also need to unlearn constructions? The case of constructional negative transfer from Spanish to Italian and its pedagogical implications - 237

\section{Constructing a constructicon for L2 learners}

Bert Cappelle and Natalia Grabar

Towards an n-grammar of English -271

Hans C. Boas, Ryan Dux and Alexander Ziem

Frames and constructions in an online learner's dictionary of German - 303

Lisa Loenheim, Benjamin Lyngfelt, Joel Olofsson, Julia Prentice and Sofia Tingsell Constructicography meets (second) language education: On constructions in teaching aids and the usefulness of a Swedish constructicon - 327

Index 357 


\title{
Do we also need to unlearn constructions? The case of constructional negative transfer from Spanish to Italian and its pedagogical implications
}

\begin{abstract}
In order to ascertain whether Spanish-speaking learners of Italian transfer two frequent Spanish partially-filled-in constructions to Italian, we carried out an experiment using a picture-based dialogue description task and immediate recalls. We divided our sample of informants into two groups: group A comprised 8 subjects with long-term exposure to Italian but almost no formal instruction, whereas group B was composed of 10 subjects with short-term exposure and three months of formal instruction in a university context. The Spanish constructions considered in this study are the planned future periphrasis [ir $a+$ infinitive] ('go to' + infinitive), the iterative periphrasis [volver $a+$ infinitive] ('return to' + infinitive) and their Italian literal equivalents. In Italian, overlapping syntactic templates (i.e. [andare $a+$ infinitive] ('go to' + infinitive) and [tornare $a$ + infinitive] ('return to' + infinitive)) are mainly limited to the expression of spatial-displacement meanings: iteration and planned future are usually expressed by affixation, lexical means and/or verbal morphology. The results of our study highlight that neither long-time exposure to Italian nor formal instruction (when not specifically directed to the issue tackled here) are sufficient to help Spanish-speaking learners unlearn the L1-based features used to construct iterative and planned future meanings. Therefore, drawing on a Cognitive Linguistics-inspired approach to language pedagogy, three kinds of pedagogical interventions aimed at discouraging this negative transfer phenomenon are described and discussed.
\end{abstract}

Keywords: Italian constructions; planned future construction; iterative construction; Spanish learners; exposure effect; instruction effect; unlearning process

\section{Introduction}

The need for a cognitive grounding for any pedagogical grammar has been addressed by scholars interested in applying the principles of Cognitive Linguistics (CL) to language pedagogy (De Rycker and De Knop 2009; Holme 2012; Ruiz de 
Mendoza Ibáñez this volume). "Cognitive grounding” means, in broad terms, helping the learner recognize, understand and interiorize the cognitive mechanisms - such as conceptual metaphors, metonymies or figure-ground alignment that rule the grammar of the target language. In recent years, various studies have proved that activities aimed at raising students' awareness of the nonarbitrariness of grammar are successful teaching interventions, particularly in those areas where the foreign language (L2) and the mother tongue (L1) diverge (see inter alia Holme 2010; Lysinger 2015; Tyler 2008; Tyler, Muller, and Ho 2011). A CL-principled pedagogical grammar indeed acknowledges a central role for contrastive analysis between L1 and L2, which is useful to predict those areas of the L2 in which teacher intervention is more needed (De Knop and Perrez 2014; Ruiz de Mendoza Ibáñez 2008, this volume).

Cognitive approaches to grammar teaching so far have largely been concerned with suggesting pedagogical activities that can help learners acquire new constructions, i.e. form-meaning pairings that must gradually be included in their interlanguage. However, up to now - to the best of our knowledge one of the central issues of language acquisition and teaching, namely the transfer of constructions from L1 to L2, has hardly been considered. The effects of transfer, defined as "the influence of a person's knowledge of one language on that person's knowledge or use of another language" (Jarvis and Pavlenko 2008: 1) are stronger and longer-lasting when the L1 and the L2 are genetically and typologically related. In this case (which is the situation considered in this paper), the learners identify structures or properties common or apparently common to the two languages (Odlin 1989: 113-114; Ringbom 2007: chap. 4). The learning of the $\mathrm{L} 2$ will be facilitated by the resemblance of the two systems, especially in receptive tasks (Ringbom 2007: 11); however, learners will find it difficult to get rid of many transfer-generated errors, usually highly fossilized and impervious to pedagogical intervention. Therefore, teaching activity should help students learn new constructions but also unlearn L1-based form-meaning pairings, i.e. de-entrench L1 routines from learners' interlanguage.

This chapter is devoted to this rather neglected area, focusing on the transfer of two frequent partially-filled-in constructions (Goldberg 2003) from Spanish into Italian, viz. the planned future periphrasis (PFP) and the iterative periphrasis (IP). PFP is a tempo-aspectual periphrasis constructed in Spanish by a finite form of the verb ir ('go'), the preposition $a$ ('to') and a meaning-bearing verb in the infinitive form. Its template is [ir $a+$ infinitive] (1):

(1) Spanish

¿Qué vamos a hacer mañana?

What go.1PL.AUX PREPOSITION do.INF tomorrow?

'What are we going to do tomorrow?' 
PFP is "associated to the values of immediacy, proximity to the act of speech, intentionality, or the speaker's conviction that the events situated in a future time will be performed" (Blas Arroyo 2008: 88). We use the label "planned future" to refer to this cluster of meanings (Aaron 2006).

IP is a tempo-aspectual periphrasis constructed by a finite form of the verb volver ('return'), the preposition $a$ ('to') and a meaning-bearing verb in the infinitive form. Its template is [volver $a+$ infinitive] (2):

\section{(2) Spanish \\ Vuelvo a leer el libro \\ Return.1SG.AUX PREPOSITION read.INF the book \\ 'I read the book again'.}

IP conveys the iterative and the restitutive aspect. ${ }^{1}$

According to constructionist approaches to grammar à la Goldberg, PFP and IP can be considered partially-filled-in constructions: one of their three configurational slots is variable (the infinitive verb) while the other two are lexically fixed in order to arrive at a grammatical construct (Brems 2011: 71). Partially-filled-in constructions are linguistic patterns (Goldberg 2003: 219) whose global meaning is constructed independently of the lexical meanings of their constituent content words, i.e. is not inferable by the simple semantic sum of their components.

These two constructions have only formal but not functional Italian counterparts. Italian displays perfectly overlapping syntactic templates which, unlike Spanish, construct rarer or not perfectly overlapping tempo-aspectual meanings. The formal Italian counterpart of PFP is [andare $a+$ infinitive] (andare being the Italian for ir, 'go'). The formal Italian counterpart of IP is [tornare $a+$ infinitive] (tornare being the Italian for volver, 'return'), which can be used to convey, besides physical displacement meanings, only the restitutive aspect and not the iterative one (Rosemeyer in press). In examples (3) and (4) only physical displacement meanings are expressed:

\section{(3) Italian \\ Vado a lavorare in ufficio \\ Go.1SG. PREPOSITION work.INF PREPOSITION office \\ 'I go to work in the office'}

1 In this work and elsewhere (Della Putta 2015), we distinguish the iterative and the restitutive aspect. With the latter we refer to the restoration of a previous state of affairs, whereas with the former we mean the repetition of an action. As Rosemeyer (in press) points out, Italian and Spanish IP differ strongly in respect to this point: the Italian IP can be used to convey restitutive meanings only, whereas the Spanish IP can be used to convey both iteration and restitution. 
(4) Italian

Torno

$a$

far-mi

la doccia

Return.1SG PREPOSITION

do.INF-REFL.1SG the shower

'I go back to take a shower'

As we will see in detail in the following paragraphs, Spanish-speaking learners of Italian (SLI) face the difficulty of not relying on constructions of the type (3) and (4) to construct planned future and iterative meanings.

The aim of this chapter is twofold. First, we analyse whether input exposure and, albeit to a lesser extent, instruction can have an impact on the transfer of the Spanish PFP and IP. To verify this, we studied the possible negative transfer between two groups of SLI: group A consisted of virtually non-instructed but long-term input-exposed SLI, whereas group B was composed of instructed but short-term input-exposed SLI. The two groups completed a picture description and an immediate recall task in order to evaluate if either longer exposure to input or instruction can lead to a reduction of the negative transfer of these Spanish-based items.

Second, we briefly propose pedagogical interventions following the principles of a CL-based pedagogy that can be effectively brought into the classroom with the aim of discouraging the transfer of these structures.

\section{Planned future and iteration in Spanish and Italian}

Spanish and Italian are closely related languages in the Romance family, sharing a mutually intelligible phonetic system, a Latin-based lexical inventory, an inflective morphology, and similar syntax (Green 2009). For the aim of this study, we focus on the syntactic characteristics of these languages. The syntactic features of Spanish and Italian largely converge (Carrera Díaz 2007; Schmid 1994), thus giving the apparent image of two perfectly overlapping systems. Nevertheless, a few subtle differences do emerge and are those whose learning has proven to be more difficult. The presence of Spanish-based syntactic features in SLI's interlanguage has been detected by numerous studies even after long periods of formal education or input exposure (De Benedetti 2006; Ferrario 2013; Schmid 1994; Zurlo 2009).

We focus here on the transfer of PFP and IP in SLIs' interlanguage. Both PFP and IP can be used in Spanish with a literal meaning, thus expressing only spatial displacement, and in a periphrastic way, thus with tempo-aspectual meaning (García-Miguel 2005; Olbertz 1998): 
(5) Spanish

Paco va a escribir un libro sobre su teoría

Paco go.3SG PREPOSITION write.INF a book about his theory

The literal meaning is: 'Paco goes to write a book about his theory';

The periphrastic meaning is: 'Paco is going to write a book about his theory'.

(6) Spanish

Volviò a duchar-se

returned.3SG PREPOSITION take a shower.INF-REFL.3SING

The literal meaning is: 'He returned to take a shower';

The periphrastic meaning is: 'He took a shower again'

(both examples from Olbertz 1998: 231).

The literal meaning is constructed by the simple semantic combination of the constituents, while the tempo-aspectual meaning is obtained by referring to the metaphorical mapping of time onto space (Lakoff and Johnson 1980) which transfers the meanings of the verbs ir ('go') and volver ('return') from a spatial to a temporal domain. Only in this second case can we speak about partially-filledin constructions in a Goldbergian sense (Goldberg 2003) as only in this case do these patterns arrive at a global meaning that is not inferable from the simple semantic sum of their components.

Following Boas' (2010) ideas about the usefulness of a constructional contrastive analysis, we now examine how Italian expresses planned future and iterative meanings. Boas (2010) maintains that a study of how the same meanings are cross-linguistically mapped to different forms should begin by comparing pairs of languages whose constructional repertoire has already been carefully described. In this way we can identify and explain cross-linguistic constructional generalizations and, at the same time, keep a record of language-specific constructional properties.

As we have briefly seen in the introduction, PFP and IP have only nontempo-aspectual counterparts in Italian (examples (3) and (4)). The iterative meaning constructed by IP in Spanish (7a) is commonly expressed in Italian by lexical means $(7 \mathrm{~b})$ or by affixation, in the latter case by the use of the verbal affix ri- (7c):

(7) a. Spanish ¿Cuándo volvemos a vernos? When return.1PL.AUX PREPOSITION see.INF.REFLEXIVE.PRONOUN 
b. Italian

Quando ci vediamo di nuovo?
When we.REFLEXIVE.PRONOUN see.1Pl of new
Italian
Quando ci ri-vediamo?
When we.REFLEXIVE.PRONOUN ITERATIVE.AFFIX.see.1PL
All examples: "When are we going to see each other again?"

The planned future, constructed in Spanish by the PFP (8a), is mapped in Italian to the simple present (8b) or the simple future (8c) of the verb:

(8) a. Spanish

$\begin{array}{lllll}\text { ¿Qué } & \text { vamos } & a & \text { hacer } & \text { mañana? } \\ \text { What } & \text { go.3PL.AUX } & \text { PREPOSITION } & \text { do.INF } & \text { tomorrow? }\end{array}$

b. Italian

Che facciamo domani?

What do.PRES.3PL tomorrow

c. Italian

Che faremo domani?

What do.FUT.3PL tomorrow

All examples: "What are we going to do tomorrow?"

It must be mentioned that in recent years some scholars have raised the question of whether the Italian [andare $a+$ infinitive] ('go to' + infinitive, formally identical to the Spanish PFP as exemplified in the introduction) expresses a tempo-aspectual meaning similar to that constructed by the Spanish PFP. Bertinetto (1991) and Amenta and Strudsholm (2002) attest only statistically rare resultative periphrastic values for [andare $a+$ infinitive]. According to Valentini (2007), [andare $a+$ infinitive] displays unstable and less recurrent resultative and iterative values instantiated by some highly frequent transformative, continuative and resultative verbs. With frequent permanent and non-permanent stative verbs such as essere ('be') and avere ('have') no periphrastic meaning is attested, contrary to Spanish usage. Furthermore, the periphrastic value of [andare $a+$ infinitive] is restricted to oral use or to less prestigious varieties of Italian and is not attested either in descriptive or in pedagogical grammar books because of its instability of use. Let us now examine how and why the Spanish PFP and IP are transferred by SLI to Italian. 


\section{Unlearning constructional transfer}

According to the embodied semantic paradigm (Violi 2012), human beings conceptualize abstract domains such as time or aspect via conceptual metaphors, that is, by relying on concrete and bodily-experience based domains such as space. Odlin (2008) maintains that L1 figurative language is easily transferred into learners' interlanguage. The transferability of figurative language is facilitated by the fact that some metaphorical relations are widespread, if not universal: as it seems likely that every culture and every language map time onto space (Weger and Pratt 2008), it will be easy for learners to "assume certain constructions to be universal when in fact they involve language-specific meaning extension" (Odlin 2008: 325).

In the following examples we can see how SLI generate non-target sentences by transferring the Spanish PFP and IP to Italian: ${ }^{2}$

(9) $\quad$ Professore, che andiamo a studiare, oggi?

'Professor, what are we going to study today?'

(10) ${ }^{\circ}$ Da domani vado a essere un bravo studente...

'Starting from tomorrow, I am going to be a good student'

(11) ${ }^{\star}$ Dobbiamo tornare a leggere il paragrafo, ora?

'Do we have to read the paragraph again now?'

In these examples, according to a detection-based approach to transfer ${ }^{3}$ (Jarvis 2012), planned future meanings (examples (9) and (10)) and the iterative aspect (11) are constructed by erroneously using the non-constructional Italian counterparts of the Spanish PFP and IP. Instead of using target-like Italian means such as finite verbal morphology or affixation (see Section 2), SLI relied on the formal similarity of Spanish and Italian to construct planned future and iterative meanings, without being aware that Italian does not share the tempo-aspectual values of these syntactic patterns with Spanish.

Three factors can be put forward to account for such transfer phenomena. First we can refer to 'psychotypology' (Kellerman 1983), according to which transfer effects are stronger when the $\mathrm{L} 1$ and the $\mathrm{L} 2$ are thought by the learners

2 These utterances were produced by SLI during real lessons where the author of this chapter was the instructor.

3 The detection-based approach to transfer is defined by Jarvis (2012: 1) as "the detection of language-use patterns that are characteristic and distinctive of learners from specific L1 backgrounds". 
to be typologically similar (Ringbom 2007). As shown by Bailini (2012) and Landone (2001) this often occurs with SLI.

Secondly, the 'transfer to somewhere' principle (Andersen 1983) states that a structure from the L1 is more easily transferred if the learners find or think they have found a "similar counterpart" (Jarvis and Pavlenko 2008: 174) in the L2. We put forward the idea that this is the case with SLI as they will surely find in the Italian input similar syntactic templates such as [tornare $a+$ infinitive] ('return to' + infinitive) and [andare $a+$ infinitive] ('go to' + infinitive). As soon as the meanings of Italian tornare and andare are equated with those of Spanish volver and ir, SLI will assume that they can rely on these syntactic templates also to express tense/aspectual meanings: the constructional negative transfer is triggered by the structural - but not functional - cross-linguistic resemblance between the two analytical constructions.

Finally, strong syntactic priming effects in bilinguals, L1 and L2 learners have been discovered by scholars aiming to better understand the nature of syntactic priming in language acquisition (see Flett, Branigan, and Pickering 2013 and Salamoura and Williams 2007 for a review of these studies). Gries and Wulff (2005) demonstrated that the mental representations of L1 and L2 speakers are primed not only by mere syntactic patterns but also by constructions, i.e. gestaltic form-meaning pairings bearing a meaning not inferable from the semantic combination of their components.

The difficulty for SLI is that they should not transfer the constructional values of the Spanish PFP and IP to Italian, which consequently means that they have to 'unlearn' the possibility of metaphorically shifting the meaning of the two finite verbs from a spatial domain to a temporal one. In order to arrive at target-like Italian constructions of planned future and iteration, SLI need to (1) be aware that the literal equivalents of the Spanish PFP and IP are ungrammatical in Italian; (2) de-entrench their presence from their interlanguage; 3) re-engage with the Italian input in order to find the correct grammatical means to construct planned future and iterative meanings.

Unlearning an L1 structure or property means coming to understand that this structure or property is not allowed in the L2 and, therefore, avoid its transfer. The 'unlearning problem' arises when the L2 input and its pedagogical manipulations are not sufficient to make the learner aware of the ungrammaticality of certain L1-based options in the target language (Yin and Kaiser 2011: 182). The target language can only provide 'positive evidence' of what is correct, but it fails to provide the 'negative evidence' needed to reveal the incorrectness of certain L1 properties transferred to the L2 (Gass and Mackay 2002). In such cases learners cannot generalize negative evidence from the input alone, i.e., in our case, the fact that two crosslinguistically analogous structures do not corre- 
spond to similar functions. It is therefore maintained by various scholars, working under both functional and generative paradigms (Gass and Mackay 2002; Lefebvre, White, and Jordan 2006), that the L1 influences learners' interlanguage more strongly and for longer in those domains where the input fails to provide robust evidence of what is ungrammatical in the target language.

Neither long-term input exposure nor formal instruction (unless focused on these transfer phenomena) can help students solve the unlearning problem, as confirmed by various studies (Inegaki 2001; Larrañaga et al. 2012; White 1991). In the study by Larrañaga et al. (2012) it is demonstrated that L1 English students of Spanish transfer English satellite configuration of particular motion events (boundary crossing) independently of their proficiency and length of exposure to the L2. Larrañaga and colleagues justify this persisting transfer-generated error in terms of a lack of positive and negative evidence in learners' exposure to L2 input: the expression of the manner of motion in Spanish is low salient and rare and it is never part of a syllabus designed for English-speaking students.

Similar considerations emerge from Inegaki's (2001) study. This was designed to test the hypothesis according to which L1 Japanese learners of English should be able to learn manner-of-motion verbs with goal prepositional phrases (PPs) in English from positive evidence, whereas L1 English learners of Japanese should be unable to learn that these constructions are impossible in Japanese because nothing in the input would tell them so. In English both manner-ofmotion (such as walk or run) and directed motion verbs (such as go or enter) can occur with goal PPs, while in Japanese only directed motion verbs occur with goal PPs. The results of the study confirm the initial hypothesis: L1 Japanese learners of English experience less difficulty than their L1 English counterparts. The former can rely on the positive evidence provided by the input and thus 'add' a configuration to their L1 motion verbs argument structure, while the latter are shown to be unable to unlearn an L1-based argument structure (mannerof-motion verbs with PPs): this construction has proved to be constantly transferred to their interlanguage.

White's (1991) study focuses on English and French dative constructions. English allows for both prepositional and double-object datives (examples (12) and (13)), whereas in French, when the dative object is nominal, only prepositional datives are allowed ${ }^{4}$ (examples (14) and (15)), sentence (15) being incorrect:

4 If the dative is a pronoun, even French allows for a double-object construction, e.g. Jean lui a donné le livre ('John gave him the book'). 
(12) John gave the book to Mary

(13) John gave Mary the book

(14) French

Jean a donné le livre à Marie

Jean have.3SG.AUX. given the book to.PREP Marie

(15) French

*Jean a donné Marie le livre

Jean have.3SG.AUX given Marie the book

High-proficiency L1 English speakers of French considered (15) correct, ignoring the fact that French does not allow the double-object dative. The unlearning problem of double-object datives arises because nothing in the French input suggests that sentences such as (15) are not correct; the mere fact that learners do not find such structures in the input does not seem to be sufficient to avoid the transfer of such syntactic templates. French-speaking learners of English, on the other hand, use the English double-object dative as they can find positive evidence for it in the input they process.

Unlearning thus seems more troublesome than learning (Gabriele 2009; Schwartz 1998; Yin and Kaiser 2011) and in order to unlearn L1 features transferred to the L2, learners need explicit negative evidence provided by teacher interventions. We turn to this in the following sections.

\section{Study}

The transfer of the Spanish PFP and IP to Italian is reported in various nonexperimental studies with different theoretical perspectives: sociolinguistic (Vietti 2005: 120-121), contrastive (Carrera Díaz 2007), pedagogical (De Benedetti 2006; Ferrario 2013; Morgana and Zaffaroni 2010; Zurlo 2009). The transfer of PFP is widely reported in all these studies, while the transfer of IP is attested to a lesser extent. The aim of these studies is descriptive and mainly based on the experience of Italian language teachers. Even though teachers' reports are a valid means to investigate cross-linguistic influence (Jarvis 2012: 11), we believe that more experimental evidence is needed to clearly state that these Spanish constructions are commonly part of SLI interlanguage. 
The purpose of our study is therefore to answer the following research questions:

1) Do SLI receiving almost no explicit instruction but long-term input exposure (group A) and SLI receiving explicit L2 instruction (but without a specific focus on the constructions in question) over short-term input exposure (group B) both use the Italian counterparts of the Spanish PFP and IP respectively [andare $a+$ infinitive] ('go to' + infinitive) and [tornare $a+$ infinitive] ('return to' + infinitive) - to express future planned and iterative meanings instead of relying on the target-like Italian linguistic means (affixation, lexicon of verbal morphology, see Section 2)?

2) Is there a (quantitative or qualitative) difference between group $A$ and group $\mathrm{B}$ in the way these constructions are transferred?

If the transfer of these constructions is confirmed by our data and if no difference between the two groups is found, this will support the idea that neither long-term exposure to input nor not-focused instruction are sufficient to help SLI unlearn the recourse to these ungrammatical structures; this, then, would highlight the need for planned and targeted teaching intervention to help learners unlearn the use of these partially-filled-in constructions.

It has been pointed out to us that the main variable that distinguishes the two groups of SLI enrolled for this study is input exposure and not instruction for two main reasons: 1) as we will describe in the section below, some of the participants in group A have received a small amount of formal instruction and this of course weakens this distinctive feature of group A compared with group B; 2) group B has received formal instruction that was not directed explicitly at the issues addressed in this paper and therefore instruction should not be considered as a variable that clearly distinguishes between the two groups.

We agree that the strongest variable differentiating A from B is input exposure but we think it is also correct to consider, albeit as a less distinguishing variable, the fact that group B has received formal instruction in Italian. There are two reasons for our claim: 1) the instruction received by group B can at the very least be considered as a supplementary and better organized input received and processed by the learners during their stay in Italy ( 3 months) and during previous course(s) followed in their home country (Spain); 2) group B received instruction in both Spain and Italy. Even though the instruction provided in Italy was controlled in order not to give any explicit information or correction on the transfer of PFP and IP, the same cannot be firmly stated about the instruction received in Spain. The courses attended before our study were designed for beginner L1 speakers of Spanish and were probably of a comparative L1-L2 nature. Although 
it would be rare for such courses to deal with the transfer of PFP and IP (despite their comparative characteristics), we cannot be sure that in these courses no explicit correction or mention of this issue was made. We therefore reframe the two variables used to distinguish the two groups: the main variable is input exposure, which differs greatly between the two groups, but we feel it is necessary to at least mention instruction for the above reasons.

\subsection{Participants}

26 subjects took part in the study and fell into 3 groups. Group A was composed of 8 long-term exposed and almost non-instructed SLI; group B was composed of 10 short-term exposed instructed SLI. A third group, group C, comprised 8 monolingual Italian native speakers and was used as a control group. Details about the groups are provided in the following subsections.

\subsubsection{Group A}

Group A was composed of eight almost non-instructed SLI, aged 26 to 42 and living in Milan. By 'almost non-instructed' we mean: 1) that the amount of formal instruction for Italian declared by the subjects did not exceed three months and 2) that this instruction did not have a Spanish-Italian contrastive basis, i.e. it was designed for multilingual classes. Self-study cases were also considered: none of the eight subjects had taken online, one-to-one conversation lessons or had studied Italian with contrastive Spanish-Italian grammars or textbooks. The most important criterion followed to identify potential subjects for group A was the length of their stay in Italy, which had to be no less than three years, thus ensuring long-term exposure to Italian for all eight participants.

Proficiency level in Italian had to be comparable with that of participants from group B. In order to evaluate this, all eight subjects from group A took and passed the B1 level in the CILS (Certificazione Italiano Lingua Straniera) examination, one of the official proficiency certifications released by the University for Foreigners of Siena and recognized by the Italian Ministry of Education. The exam used to assess proficiency level in group A was that used for the June 2012 session, downloadable at: http://cils.unistrasi.it/89/197/Prove_Liv._B1.html (last accessed on 22/05/2014). The features of the eight subjects in group A are summarized in Table 1. 
Table 1: Features of subjects in group A

\begin{tabular}{llll}
\hline Acronym & Age & Formal instruction & Period of stay in Italy \\
\hline A1 & 26 & 3 hours per week for 3 months & 3 years and 6 months \\
A2 & 35 & Self-study with Italian grammar books & 5 years and 2 months \\
A3 & 37 & None & 3 years and 8 months \\
A4 & 42 & $\begin{array}{l}\text { Self-study with grammar books after his arrival } \\
\text { in Italy }\end{array}$ & $\begin{array}{l}\text { Approximately 5 years } \\
\text { with some long periods } \\
\text { abroad }\end{array}$ \\
& & & Formal lessons at a local private school for two \\
A5 & 40 & years \\
A6 & 28 & None & 3 years and 8 months \\
A7 & 36 & Some weeks of formal instruction on her arrival & 5 years \\
A8 & 41 & None & 6 years and 3 months \\
\hline
\end{tabular}

\subsubsection{Group B}

Group B comprised ten instructed SLI, aged 20 to 26 and living in Bologna. All of them were Spanish university exchange students enrolled in a 60-hour course of Italian lasting three months. The entry level of these students was assessed via an entry test (both written and oral) and all were placed at the A2 level of the Common European Framework of Reference for Languages (CEFR). All participants had studied Italian formally in Spain. The class they were assigned to was taught by the author of the present chapter and was made up of sixteen SLI. The syllabus followed during the three-month course was aimed at: 1) improving performance of both receptive and productive tasks; 2) reviewing the most difficult features of Italian grammar studied in previous courses; 3) introducing new grammar elements to their interlanguage, such as the simple future and conditional.

During the course in Italy no contrastive analysis between Italian and Spanish was performed as far as PFP and IP were concerned. At the end of the course, the students took the same CILS B1 proficiency test as the subjects in group A. The ten subjects who passed the exam were asked to voluntarily participate in the study. The features of the ten subjects in group B are summarized in Table 2. 
Table 2: Features of subjects in group B

\begin{tabular}{|c|c|c|c|}
\hline Acronym & Age & Formal instruction & Period of stay in Italy \\
\hline B1 & 22 & Around 50 hours in Spain and 60 hours in Italy & 4 months \\
\hline B2 & 20 & $\begin{array}{l}\text { One month (hours not specified) in Spain and } \\
60 \text { hours in Italy }\end{array}$ & 3 and a half months \\
\hline B3 & 26 & 60 hours in Spain and 60 hours in Italy & 5 months \\
\hline B4 & 23 & 40 hours in Spain and 60 hours in Italy & 6 months \\
\hline B5 & 22 & Two months in Spain and 60 hours in Italy & 4 months \\
\hline B6 & 23 & 60 hours in Spain and 60 hours in Italy & 5 and a half months \\
\hline B7 & 24 & Two months in Spain and 60 hours in Italy & 4 months \\
\hline B8 & 22 & 50 hours in Spain and 60 hours in Italy & 4 months \\
\hline B9 & 23 & One month in Spain and 60 hours in Italy & 5 months \\
\hline B10 & 21 & $\begin{array}{l}60 \text { hours in two months in Spain and } 60 \text { hours } \\
\text { in Italy }\end{array}$ & 4 months \\
\hline
\end{tabular}

\subsubsection{Group C}

Group C was composed of eight Italian monolingual mother tongue subjects aged 29 to 38, all living in Milan. Subjects volunteered to participate in the study and were not aware of its aims. The eight subjects were selected mainly because their Italian could be classified as "standard Italian”, i.e. a variety of Italian with no strong diatopic influence spoken commonly (but not exclusively) by highlyeducated individuals living in northern industrial cities such as Milan and Turin (Dal Negro and Vietti 2006). All participants were graduates, but none had studied linguistics or related subjects.

\subsection{Design of the study}

The 26 subjects completed a picture-based task in which they were asked to complete the dialogues or the monologues of characters acting in planned future (pictures 1-4, Figure 1) or iterative contexts (pictures 5-8, Figure 2).

The task was performed orally: the subjects were sitting opposite the researcher who recorded their answers. The instructions were given in Italian according to the following formula: "Look at these pictures and complete the utterances with the words that sound best to you". We decided to use a strongly guided picture task in order to restrict as much as possible the linguistic options that could be used in the communicative contexts. 


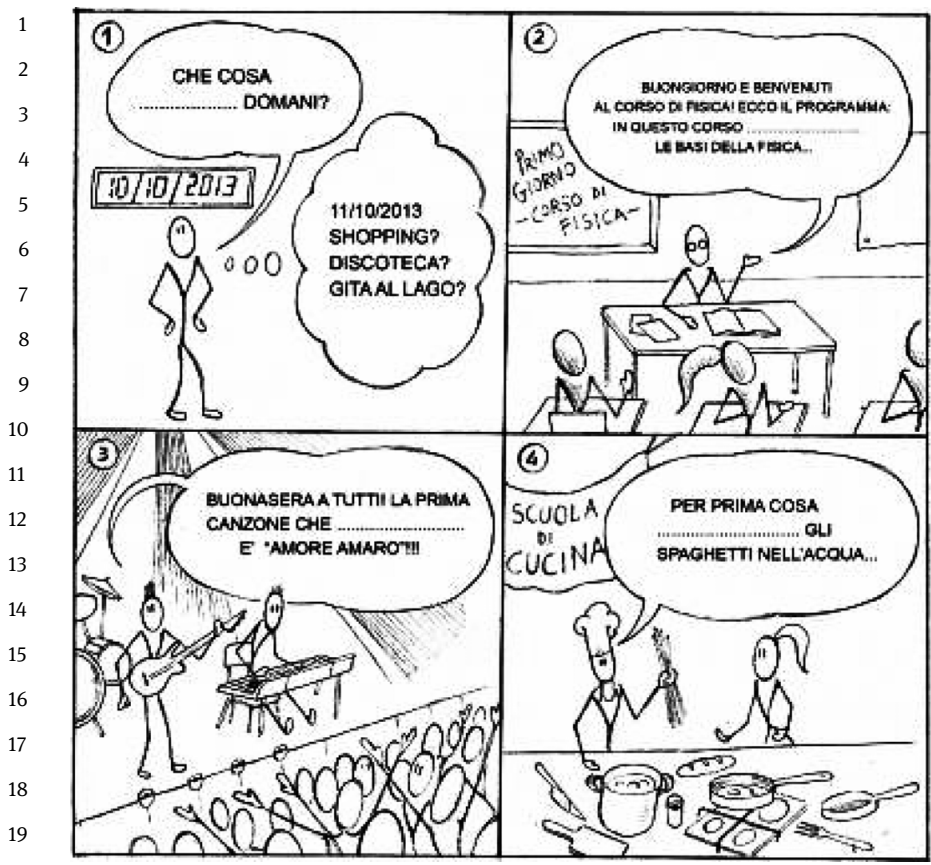

Figure 1: Planned future contexts 5

After all the answers were given, the participants took an immediate recall test, which was delivered in Italian according to the following formula: "Can you tell me why you chose to complete this sentence with ?”. The aim was to try to understand the reason(s) that led the subjects to use particular linguistic items. It must be noted, however, that not all the subjects understood the question and some failed to answer.

\subsection{Results of group C}

For the stimuli used, we had assumed that in no case could the use of [andare $a+$ infinitive] ('go to' + infinitive) and [tornare $a+$ infinitive] to express planned

5 Translation of Figure 1 (planned future contexts): Scene 1: "What ......... tomorrow?" // "Shopping? Disco? Trip to the lake?". Scene 2: on the blackboard: "First day - Physics course” // "Good morning and welcome to the Physics course. Here is the programme: in this course ......... the basis of Physics". Scene 3: "Good evening everybody! The first song that ....... is "Bitter Love"”. Scene 4: written in the background: "Cooking school." // "First ....... the spaghetti in the water." 


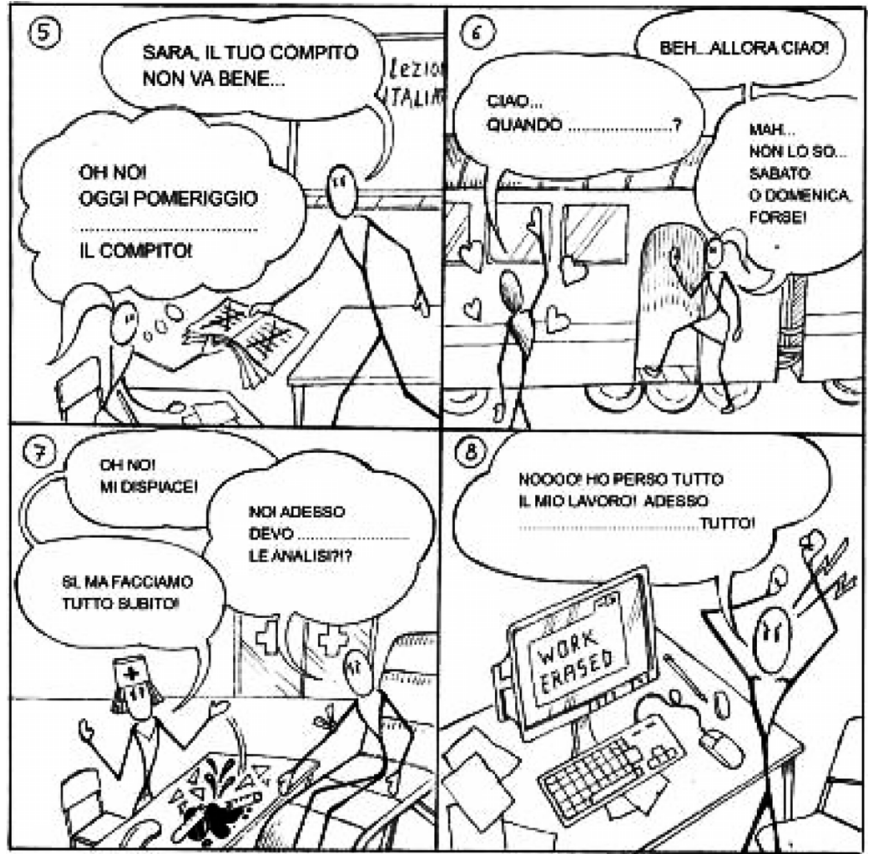

Figure 2: Iterative contexts 6

future and iteration be judged as grammatical in Italian. Nevertheless, as previously seen in Section 2, there are cases where the use of [andare $a+$ infinitive] ('go to'+ infinitive) with similar constructional values to those of the Spanish PFP is recorded in oral and less prestigious varieties of Italian. Therefore, to better evaluate the performance of group $A$ and $B$ with respect to this issue, we first present the data from group $C$ in order to see how many times Italian mother tongue speakers used such patterns to complete the eight utterances.

A qualitative analysis of the answers shows that pictures 4 and 8 were interpreted differently than expected by the author. In picture 4, three informants used the imperative form and one informant selected the modal verb dovere ('have to') because in this situation the role of the cook was judged as hierarchical

6 Translation of Figure 2 (iterative contexts): Scene 5: Teacher: "Sara, your homework is not good." // Student: "Oh no! This afternoon ........... the homework”. Scene 6: Girl: "Well, then... goodbye...”. // Boy: “Goodbye... when..........?” // Girl: “Well, I don’t know... Saturday or Sunday, maybe!”. Scene 7: Nurse: “Oh no, I am so sorry!” // Patient: “Oh no, now I have to .......... the blood test?!” // Nurse: "Yes, but we will do everything very quickly”. Scene 8: "Oh no, I have lost all my work! Now everything!" 
towards the woman, as emerged from the immediate recall task. The three imperative forms and the modal verb dovere were not included in the final scoring as the subjects did not interpret picture 4 as bearing a planned future meaning.

Picture 8 had been intended to elicit an iterative meaning but four informants out of eight interpreted it as a planned future meaning: "Here I used rompo ('I break') because the person is angry with his computer and he surely wants to break it", 7 one informant said; three other informants reported similar thoughts. We therefore decided to compute the different answers according to the subjects' interpretation: four of them were calculated as planned futures and four as iteratives.

Out of 32 answers about planned future meanings, one (2.7\%) was given in picture 4 with [andare $a+$ infinitive] ('go to' + infinitive). Iterative meanings were always constructed by resorting either to affixation (ri-) or to lexical means such as di nuovo or ancora ('again').

The subject who used [andare $a+$ infinitive] ('go to' + infinitive) for picture 4 failed to explain his choice: "I said andiamo a buttare ('we go to throw') because the cook is doing an action that is also useful for the woman... he is teaching her, he is involving her in what he is doing". This explanation seems to account for the choice of a first person plural form rather than a singular one, but does not clearly state why the informant used the [andare $a+$ infinitive] template in this case.

\subsection{Results of group A}

Turning now to the results of group A, it appears that in two cases subjects failed to answer, i.e. they were not able to fill the gaps in the captions. Similarly to the situation for group $\mathrm{C}$, pictures 4 and 8 elicited unexpected answers: picture 4 elicited a directive modality four times and these were not included in the final scoring; picture 8 elicited a planned future five times and an iteration three times. The immediate recall task highlighted very similar reasons for these choices to those expressed by subjects in group $\mathrm{C}$.

For pictures 1 and 2, four answers were not calculated because the subjects interpreted the characters' thoughts and utterances as expressions of doubt between different eligible options: the verbs potere and volere ('can' and 'want') were used. For picture 5, two answers were excluded because A6 and A8 did not recognize a possible iteration in the situation.

7 Here and elsewhere in the chapter we report the subjects' motivations for their linguistic choices. The answers were given in Italian or, partially, in Spanish by subjects of group A and B. All the translations are our owns. 
Out of 28 answers about planned future meanings, 17 were PFP-based, which corresponds to a percentage of $60.7 \%$. The iterative meaning was constructed 13 times out of 22 by resorting to an IP-based pattern, making up 59\% of the answers.

The immediate recall task only partially highlighted the reasons why subjects chose to use PFP and IP Italian counterparts. We report here some of the most significant answers which partially explained this point.

A2 reports for pictures 1 and 3: "well, I said vado a fare ['I go to do'] because he is thinking about tomorrow [...] here I said vado a cantare ['I go to sing'] because the concert has just begun".

A3's motivation for the use of lexical and IP-based means in pictures 5 and 6 respectively to construct iterative meanings shows that the two options are considered equivalent: "yes, well... de nuevo [Spanish for 'again'], vuelvo a hacer algo [Spanish for 'I return to do something'] ... they are the same situation, here the computer destroyed his work, here her homework... It is no good, says the professor, so... homework again!”.

A5 reported as follows the reasons why she used a PFP-based option in picture 2 and a simple present in picture 3: “...because the teacher wants to work with the pupils... together... so he is working with them when he says andiamo a leggere ['we go to read']... here with the concert... I don't know, but... it is only the band who sings, they are not doing it together". A5's explanation reveals the fact that according to her the two forms can be used for two different situations, thus she sees both as being available in Italian.

For pictures 1 and 2, A7 reported: "here [no. 1] I said andiamo a fare ['we go to do'] because I think that he is talking to other people and because it is a moment for the future [un momento por el futuro, cited literally] whereas for this picture [no. 2]... well, I said studieremo ['we will study'] because there are many lessons to do in a course, over a long time”. From A7's answer we can infer that she too believes that two different meanings correspond to the two choices.

A7's comment about picture 7 reveals that for her lexical and IP-based means might be equivalent: "here I said tornare a fare ['go back to do'] because, well... the tests are broken and the blood has fallen on the table [...] but maybe I can also say fare ancora ['do again'] or fare una volta più le analisi ['do the test one more time'], yes... maybe it is the same".

When A8 was asked about his choice for picture 3 (vi vado a cantare, 'I go to sing you'), he translated his answer into Spanish and overtly stated that, for him, Italian and Spanish overlap as far as PFP concerns: "es como en Español, os voy a cantar... [Spanish, 'it is like Spanish, I am going to sing you'], he sings for them and is starting in a few moments”. 


\subsection{Results of group B}

Picture 8 elicited both iterative (6) and planned future (2) interpretations. A total of 12 volitive and directive answers were not considered in the scoring procedure. Four missed answers were excluded from the final score. In picture 6, B2 interpreted the situation as a planned future and answered with mi vai a chiamare ('you are going to call me'). We computed this answer as a planned future meaning expressed by a PFP-based item.

The planned future meaning was constructed through PFP-based patterns 19 times out of 37 , i.e. in $51.4 \%$ of the answers, while the iterative meaning was constructed through IP-based patterns 12 times out of 25 , i.e. in $48 \%$ of the answers.

As for the results of the immediate recall task, we first mention B2's motivation for having answered with canteremo ['we will sing'], a simple future, in picture 3: "I do not really know why I said canteremo but this is something that is going to happen ['qualcosa che va a capitare', literal translation from Italian] in the future, so I used the future...”. It is evident from this answer that B2 does not have clear control of his linguistic choices as he wrongly transfers the Spanish PFP to Italian while motivating his use of the simple future. We further asked B2 why he decided to use andiamo a bagnare ['we go to put in the water'] for picture 4 and why he used a simple future (canteremo) for picture 3. The answer stated that "here [picture 4] the difference is that they are cooking together, whereas in number 3 they are not singing together... and also, in number 4 they are doing it in that moment ['lo stanno facendo in quello momento', literal translation from Italian], which is not what is happening here [picture 3]". B2 perceives the Italian simple future and the Spanish PFP-based pattern as two alternative options.

B5's statement shows that, as far as the construction of the iterative meaning is concerned, the subject is not aware that an IP-based pattern is not grammatical in Italian as she compares it to the lexical means she used to express iteration: "I do not really get your question... Here [picture 8] he has to do everything again, the computer destroyed his work... number 5 is very similar, she has to do the homework again because it was wrong... that is why I used ancora ['again'] and devo tornare a fare... ['I have to go back to do']".

According to B7, vado a fare ['I go to do', a PFP-based pattern] can be equivalent to faccio ['I do', grammatical in Italian for planned future], as he states: "in this first picture I used vado a fare but I think I could use faccio... I was thinking about Spanish... It would be voy a hacer [Spanish, 'I go to do'], I would say that. .. but in Italian the future is more complicated...”.

B9 explains his use of PFP-based patterns in pictures 1, 4 and 8 in this way: "these are cases where the action is planned for the future, as one can see from 
the pictures, that is why I chose to say, for example in number 8, vado a rompere ['I go to break'], etc.". In picture 3, B9 uses canterò ['I will sing'], which is grammatical in Italian for a planned future. In the immediate recall task, B9 expresses his doubts about the fact that the simple future can perhaps be substituted by either a PFP-based item or a present tense: "Canterò is a future, but now I cannot really say why I decided to use it... maybe I could also say andiamo a cantare or canto".

\section{Comparison of the results and discussion}

Results from group C further suggest that [andare $a$ ('go to') + infinitive] and [tornare $a$ ('return to') + infinitive] with periphrastic meanings expressing planned future and iteration are rare and basically ungrammatical in Italian as put forth by previous studies (see Section 2).

More specifically, for [andare $a+$ infinitive], the picture task performed by group $\mathrm{C}$ supports the position that in Italian tempo-aspectual meanings cannot be mapped to this pattern. Nevertheless, we agree with Valentini (2007) that in some contexts this mapping exists, especially in oral and less prestigious varieties of Italian: as seen in Section 4.3, it was used in $2.7 \%$ of the occurrences in our sample. The difference between Valentini's study and ours is methodological in nature: Valentini analyzed excerpts of real language, totally uncontrolled by the speakers and part of longer discourse fragments, whereas our study allowed the speakers to better control their production, which was not part of a wider discursive context. Nevertheless, our aims are pedagogical in nature and, along with recent Italian grammars (see Maiden and Robustelli 2000: 290), which do not mention its existence, we would not consider [andare $a+$ infinitive] with tempo-aspectual values as being part of an L2 Italian syllabus.

In order to answer the first research question, i.e. whether there is a difference between almost non-instructed long-term input exposure (group A) and instructed short-term input exposure (group B) as far as the transfer of the Spanish PFP and IP into Italian is concerned, we performed a Mann-Whitney U test to establish if the outcomes among the two groups show statistically significant difference. The scoring procedure for the test was operationalized as follows: 1 ) we considered correct all the answers that did not use PFP- or IP-based patterns to construct planned future or iterative meanings; 2) only planned future and iterative meanings were calculated; 3) we calculated the percentage of correct answers for each participant. 
Table 3 summarizes the degree of accuracy in the two groups as far as planned future meanings are concerned. The results of the Mann-Whitney $U$ test show that the better accuracy in group B does not have statistical significance $(U=35, p=.696)$, i.e. the two groups behaved similarly with regard to the transfer of PFP.

Table 3: Descriptive statistics on the accuracy of planned future meanings across groups

\begin{tabular}{llll}
\hline Group & $\begin{array}{l}\text { Number } \\
\text { of subjects }\end{array}$ & Mean & $\begin{array}{l}\text { Standard } \\
\text { Deviation }\end{array}$ \\
\hline A & 8 & $34.4 \%$ & 24.5 \\
B & 10 & $41 . \%$ & 15.6 \\
\hline
\end{tabular}

The descriptive statistics for the degree accuracy across the two groups for iterative meanings is summarized in Table 4. Also for iterative meanings, the results of the Mann-Whitney $U$ test show that better accuracy in group B does not have statistical significance $(U=26, p=.237$ ). Just as for planned future meanings, the two groups behaved similarly.

Table 4: Descriptive statistics on the accuracy of iterative meanings across groups

\begin{tabular}{llll}
\hline Group & $\begin{array}{l}\text { Number } \\
\text { of subjects }\end{array}$ & Mean & $\begin{array}{l}\text { Standard } \\
\text { Deviation }\end{array}$ \\
\hline A & 8 & $35.4 \%$ & 22.6 \\
B & 10 & $53.3 \%$ & 18.9 \\
\hline
\end{tabular}

Results from group C, if compared to group A and B, have statistical relevance both in the planned future and iterative conditions ( $p$ always <.05).

In conclusion, the quantitative analysis of the results of the picture task emphasises the fact that the recourse to PFP- and IP-based patterns to construct planned future and iterative meanings is equally common among both shortterm and long-term input exposed learners. The analysis of the immediate recall task helps us better understand the causes of this transfer phenomenon. There are cases in which SLI think that meanings constructed through a PFP- or IPbased patterns are comparable to those constructed by grammatically correct means in Italian such as lexis, affixation or finite verbal morphology (see the statements by A6, A7, B5 and B9).

Other subjects (A2, A5, A7 and B2) stated that in Italian PFP- and IP-based structures are syntactic templates used to construct meanings that could not be 
expressed otherwise. In such cases, SLI feel these ungrammatical patterns are necessary to express certain tempo-aspectual values.

Our results confirm that SLI (both when instructed and non-instructed but long-term-input-exposed) seem unable to infer that the transfer of the Spanish PFP and IP into Italian is ungrammatical: no real quantitative differences between the two groups are to be found and the reasons for this transfer phenomenon seem to be very similar for both groups. A properly planned pedagogical intervention is therefore needed to give SLI the indispensable amount of negative evidence that might help them notice and automatize non-recourse to PFP- and IP-based patterns.

\section{Pedagogical interventions}

In this section, we propose some pedagogical activities aimed at helping SLI unlearn the recourse to PFP- and IP-based means to construct planned future and iterative meanings. In Della Putta (2015), similar suggestions are put forward and these are tested by concretely applying them to an SLI class. We will outline three different types of intervention:

1) transcodification activities (from images to language and vice versa), which aim at explaining the embodied nature of PFP and IP and making it cognitively accessible to learners;

2) interactive strategies aimed at helping students notice the ungrammaticality of PFP and IP transfer;

3) input-manipulation activities aimed at giving learners the positive evidence of what should be used in Italian to express planned future and iteration.

\subsection{Transcodification activities}

We propose a set of pedagogical interventions whose goal is to make SLI aware of the fact that in Spanish the constructional meanings of PFP and IP are instantiated by the embodied conceptual metaphor TIME IS SPACE. As proposed by Holme (2012), the embodied origins of linguistic phenomena can be experienced by learners through both 'actual embodied routines' and 'virtual embodied principles'.

Actual embodied routines are the physical enactment of the cognitive metaphors that construct meanings or grammar rules and have been proven useful in the teaching of e.g. English motion verbs and countable and uncountable lexicon (Holme 2012; Lindstromberg and Boers 2005). In our case, the teacher can first show students pairs of sentences such as: 


\section{(16) Spanish \\ Voy a estudiar en la biblioteca \\ go.1SING PREPOSITION study.INF PREPOSITION the library 'I go/am going to study in the library'}

\section{(17) Spanish}

Mañana voy a estudiar química tomorrow go.1SING.AUX PREPOSITION study.INF chemistry 'Tomorrow I am going to study chemistry'

The non-metaphorical meaning of (16) can be mimed by enacting a movement while reading or analysing the sentence, whereas the metaphorical meaning of (17) should be highlighted by not moving at all and attracting learners' attention to the presence of the temporal adverb mañana ('tomorrow').

After having presented Spanish sentence pairs such as these, the teacher can write Italian sentences that do not construct tempo-aspectual meanings such as:
(18) Italian
Vado a lavorare
go.1SING PREPOSITION work.INF
'I go/am going to work'

(19) Italian

$\begin{array}{lllll}\text { Fra } & \text { un anno vado } & \text { a } & \text { lavorare } \\ \text { PREPOSITION } & \text { one year } & \text { go.1SING } & \text { PREPOSITION } & \text { work.INF } \\ a & \text { Roma } & & & \\ \text { PREPOSITION } & \text { Rome } & & & \end{array}$

'In one year I will go to work in Rome'

In both cases the instructor will mime a movement, attracting students' attention to the physical displacement value of the verbs and to their non-metaphorical behaviour, unlike in Spanish.

Another set of activities aimed at clarifying the cognitive mechanisms that rule students' L1 are virtual embodied principles, i.e. the use of drawings and/ or schemas to better cognize the cognitive principles essential to a language item. Csăbi (2004), Holme (2010), Tyler (2008) and Tyler, Mueller, and Ho (2011) have demonstrated the positive outcome of this kind of activity in learning English phrasal verbs, motion verbs and prepositions. 
With SLI, the teacher can show students drawings such as those in Figure 3. $\mathrm{S} /$ he can draw students' attention to the fact that these Italian analytical structures serve to construct only physical meanings (as in pictures 3 and 4), while in Spanish they are used to also convey temporal meanings. Drawings of future temporal displacement similar to pictures 1 and 2 in Figure 3 can be given as practice, asking learners to translate or describe them in Italian without resorting to any PFP- or IP- based patterns.

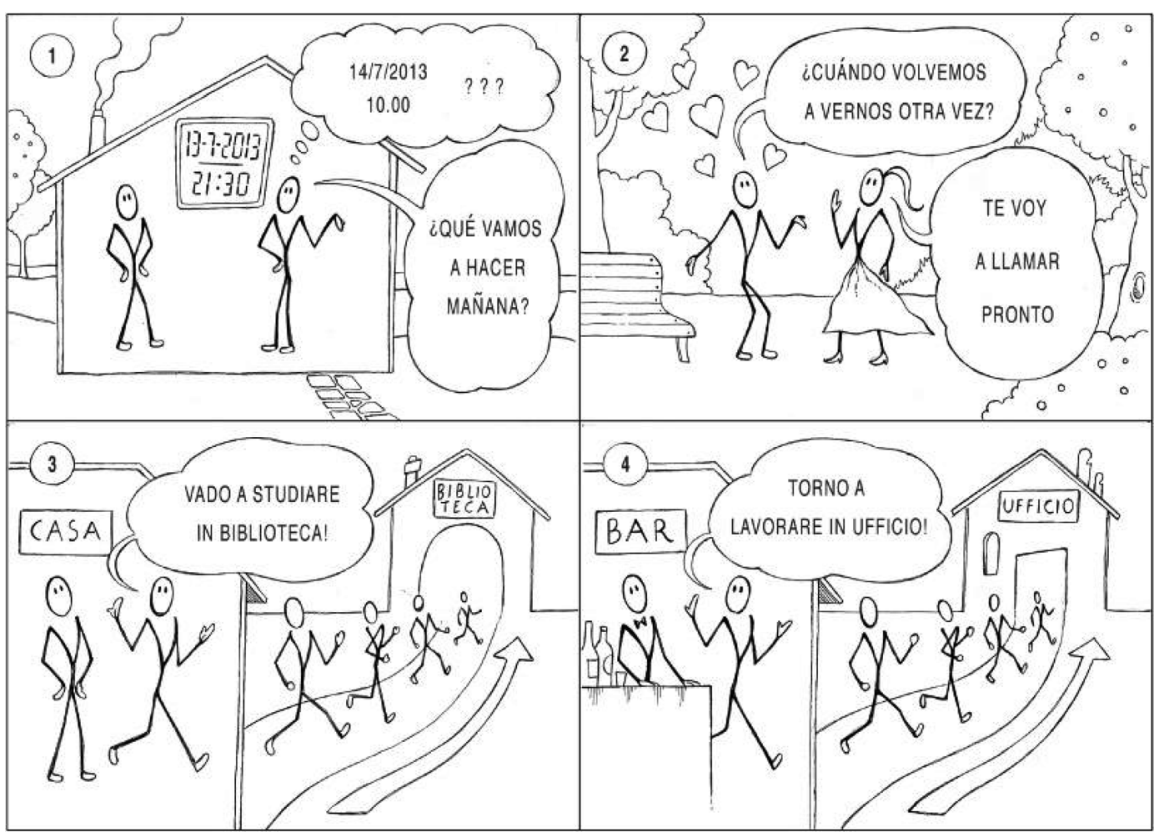

Figure 3: Drawings to be shown to $\mathrm{SLI}^{8}$

\subsection{Interactional moves}

CL-inspired pedagogy emphasises the idea that learning should be participative, stressing the fact that both students and teachers are part of a constant dialogic

8 Translation of Figure 3: Scene 1 (from Spanish): "What are we going to do tomorrow?". Scene 2 (from Spanish): Boy: "When are we going to see each other again?" // Girl: "I will call you very soon". Scene 3 (from Italian): written on the two houses, respectively in foreground and background: "house" // "library" // Boy: "I go to study in the library". Scene 4: written on the two houses, respectively in foreground and background: "bar" // "office". Boy: "I go back to work in the office". 
process where meanings and cognitive mechanisms are discovered "together" (Holme 2004: 226-227) and we consider a planned interactional strategy to be fruitful for our aims. Let us consider the interactional sequence below, quoted from two dialogues between the author and two SLI:

\section{(20) S: Per fare questo esercizio * devo tornare a leggere il paragrafo?}

T: Dove devi tornare, Alma? [faking misunderstanding]

S: Come, dove... devo tornare? Il paragrafo... [student's uptake: disorientation]

T: Devo rileggere il paragrafo? [recast of student's utterance]

S: Sì, già, non tornare ma rileggere, leggere ancora... [student's positive uptake]

T: Ok... Sì, devi rileggere il paragrafo, Alma.

S: “`To do this exercise, do I have to go back and read this paragraph?

T: Where do you have to go back to, Alma?

S: How, where... where do I have to go back? The paragraph...

T: Do I have to re-read the paragraph?

S: Ah yes, not to go back to read but re-read, to read again...

T: Ok... Yes, you have to read the paragraph again, Alma.'

By momentarily blocking a communicative event felt as natural and wellconstructed by the learner, the teacher triggers the noticing, i.e. the attentive and conscious registration (Schmidt 1995) that the IP-based pattern used is incorrect. In cognitive terms the teacher does not enter the metaphorical field erroneously created by the learner but rejects the time-space mapping.

The second interactional move we suggest is meant to repair students' errors by giving them positive evidence of the structures that should be used. As Ellis (2010) points out, the effectiveness of recast, a less intrusive and nonmetalinguistic corrective feedback technique, is strongly dependent on different variables such as the linguistic item to be corrected and learners' effective engagement with the corrections. Recasts have proven to be effective in real conversational events and are useful in drawing the students' attention to errors, especially when these arise in meaningful teacher-student interactions. We suggest that recasts are useful for our aims especially after having provided SLI with the negative evidence that the transfer of PFP and IP to Italian is incorrect. The communicative gap created by the teacher is negative evidence 
that the input alone fails to give: after this first move, students are ready to be corrected and to receive teachers' positive evidence.

\subsection{Input manipulation}

Written input can be manipulated via input enhancement techniques (Wong 2005) such as input flood or visual input enhancement. Students can be given texts where planned future and iterative values occur very frequently, and where the recourse to non-PFP- and IP-based patterns is highlighted by textual manipulations. SLI's attention should therefore be overtly drawn to the linguistic means used by Italians to express such meanings, hopefully pushing them to draw cross-linguistic comparisons between Spanish and Italian. This can be exemplified by the following short text, which focuses on the iterative aspect:

\section{Le strane abitudini del signor Rossi}

Franco Rossi è un ingegnere che ha delle strane abitudini: fa sempre tutto due volte.

La mattina si alza, torna a letto e poi si rialza ancora. Poi prepara il caffè per tutta la famiglia ma, subito dopo, lo riprepara, un'altra volta! Poi va al lavoro, entra in ufficio, esce e rientra ancora.

La sera, finalmente, torna a casa, saluta i figli, li risaluta e poi bacia e ribacia Anna, sua moglie. ${ }^{9}$

This text can be used with beginner SLI students: their attention should be drawn to the affix $r$ - and its iterative value. A simple comparison between the two languages can be made by asking students, once they have understood the meaning of $r i-$, how they would translate these verbs into Spanish, focusing on the fact that Spanish, contrary to Italian, makes use of IP.

\section{Conclusions}

In this study, an attempt was made to analyse and explain the transfer of partially-filled-in constructions from Spanish to Italian. We focused on PFP, for

9 Translation: "The strange habits of Mr. Rossi. Franco Rossi is an engineer who has strange habits: he makes everything twice. In the morning, he gets up, goes back to bed and then he gets up again. Then he prepares coffee for the entire family but, immediately after, he prepares it once more! Then he goes to work, enters his office, goes out and enters once again. In the evening, finally, he comes back home, greets his children, greets them once again and then kisses and kisses again Anna, his wife”. 
planned future meanings, and IP, constructing iterative values. The results of our study are in line with our hypothesis: the transfer of these two Spanish constructions is to be found equally in SLI with long and short input exposure. The motivation for this hypothesis lies in the failure of L2 input to provide the negative evidence needed to help SLI unlearn the recourse to L1 analytic structures to construct such meanings.

Although it comes from a small sample of informants, our data is indeed consistent with our hypothesis: neither instruction (although not focused on this phenomenon) nor input exposure are on their own sufficient, and teacher intervention is necessary to provide SLI with the negative evidence needed to align their interlanguage to native Italian in these domains.

In line with CL-inspired pedagogy, we suggested three kinds of teaching intervention that can be useful to this end: transcodification activities, interactional moves and input manipulation.

Our study focuses solely on Spanish and Italian, but we believe that similar constructional transfer phenomena can be detected within other closely-related language pairs. Studies on the acquisition of Italian by French speakers have also reported frequent transfer phenomena of the [aller + infinitive ('go' + infinitive)] construction, also expressing planned future meanings (Jamet 2009; Talé 2013). Furthermore, Dutch stative verbs such as blijven ('stay') and motion verbs such as gaan ('go') are grammaticalized by means of tempo-spatial metaphors into auxiliaries in aspectual periphrases such as (1) [blijven + infinitive] for the continuative aspect and (2) [gaan + object + infinitive] for the planned future (Lemmens 2002), something which does not happen in German, a closelyrelated language in the Germanic family. Similar constructional transfer issues might be found among Dutch-speaking learners of German, although we are not aware of work on this subject.

In conclusion, Littlemore (2011: 49-51) stresses the fact that L2 learners tend to avoid using the metaphorical meanings of words, preferring the use of their literal values, probably because learners fail to notice the metaphorical senses in the input or because "they lack the confidence to use them correctly" (Littlemore 2011: 94). We argue that, alongside the cases where the metaphorical values of certain L2 constructions have to be learned, there are other cases where recourse to L1 metaphors needs to be unlearned. Much attention has been allocated to the former case but less research and fewer pedagogical proposals have been devoted to the latter. Future directions of research could therefore focus on this, in order to evaluate if the claims made by the present paper are consistent with data from other language pairs. 


\section{References}

Aaron, Jessi. 2006. Me voy a tener que ir yendo: A corpus-based study of the grammaticization of the ir $a+$ infinitive construction in Spanish. In Nuria Sagarra \& Jacqueline Toribio (eds.), Selected proceedings of the 9th Hispanic linguistic symposium, 263-272. Somerville: Cascadilla Proceedings Project.

Amenta, Luisa \& Erling Strudsholm. 2002. Andare $a+$ infinito in italiano. Parametri di variazione sincronici e diacronici. Cuadernos de Filología Italiana 9. 11-29.

Andersen, Roger. 1983. Transfer to somewhere. In Susan Gass \& Larry Selinker (eds.), Language transfer in language learning, 177-201. Rowley: Newbury House.

Bailini, Sonia. 2012. La interlingua de lenguas afines: rasgos distintivos y perspectivas teóricas. RSEI Revista de la sociedad española de italianistas 16. 271-286.

Bertinetto, Pier Marco. 1991. Il verbo. In Luciano Renzi \& Giampaolo Salvi (eds.), Grande grammatica italiana di consultazione, 13-162. Bologna: Il Mulino.

Blas Arroyo, José. 2008. The variable expression of future tense in Peninsular Spanish: The present (and the future) of inflectional forms in the Spanish of a bilingual region. Language Variation and Change 20. 85-126.

Boas, Hans. 2010. Comparing constructions across languages. In Hans Boas (ed.), Contrastive studies in construction grammar, 1-20. Amsterdam: John Benjamins.

Brems, Lieselotte. 2011. The layering of size noun and type noun constructions in English. Berlin \& New York: Mouton de Gruyter.

Carrera Díaz, Manuel. 2007. Spagnolo e italiano: da una lingua all'altra. In Chiara Preite, Luciana Soliman \& Sara Vecchiato (eds.), Esempi di multilinguismo in Europa. Inglese lingua franca e italiano lingua straniera. La contrastività nella codificazione linguistica, 249-260. Milan: Egea.

Csábi, Szilvia. 2004. A cognitive linguistic view of polysemy in English and its implications for teaching. In Michel Achard \& Susanne Niemeier (eds.), Cognitive linguistics: Second language acquisition and foreign language teaching, 233-256. Berlin \& New York: Mouton de Gruyter.

Dal Negro, Silvia \& Alessandro Vietti. 2006. The interplay of dialect and the standard in anonymous street dialogues. Patterns of variation in northern Italy. Language Variation and Change 18. 179-192.

De Benedetti, Alessandro. 2006. Liscio come l'aceite. Errori di interferenza (e non) nell'apprendimento dell'italiano L2 in parlanti ispanofoni. In Franca Bosc, Carla Marello, Stefania Mosca (eds.), Saperi per insegnare, 205-217. Torino: Loescher.

De Knop, Sabine \& Julien Perrez. 2014. Conceptual metaphors as a tool for the efficient teaching of Dutch and German posture verbs. Review of Cognitive Linguistics 12(1). 1-29.

De Rycker, Teun \& Sabine De Knop. 2009. Integrating cognitive linguistics and foreign language teaching - historical background and new developments. Journal of Modern Languages 1. 29-46.

Della Putta, Paolo. 2015. Discouraging constructional negative transfer: Theoretical aspects and classroom activities for Spanish-speaking students of L2 Italian. In Kyoko Masuda, Carlee Arnett and Angela Labarca (eds.), Cognitive linguistics and sociocultural theory. Applications for second and foreign language teaching, 25-50. Berlin \& New York: Mouton de Gruyter. 
Ellis, Rod. 2010. A framework for investigating oral and written corrective feedback. Studies in Second Language Acquisition 32. 335-349.

Flett, Susanna, Holly Branigan \& Martin Pickering. 2013. Are non-native structural preferences affected by native language preferences? Bilingualism: Language and Cognition 16(4). 751-760.

Ferrario, Gloria. 2013. L'italiano degli immigrati ispanofoni. L'influenza della lingua 1 nell'apprendimento di lingue affini. Italiano LinguaDue 5(1). 314-340.

Gabriele, Alison. 2009. Transfer and transition in the SLA of aspect: a bidirectional study of learners of English and Japanese. Studies in Second Language Acquisition 31. 371-402.

García-Miguel, José. 2005. Verbos aspectuales en Español. La interacción de significado verbal y sognificado aspectual. In María Rio-Torto, Olívia Figueiredo \& Fátima Silva (eds.), Estudos em homenagem ao Professor Doutor Mário Vilela, 405-418. Porto: Facultades de Letras da Universidade de Porto.

Gass, Susan \& Alison Mackay. 2002. Frequency effects and second language acquisition. Studies in Second Language Acquisition 24. 249-260.

Goldberg, Adele. 2003. Constructions: A new theoretical approach to language. Trends in Cognitive Sciences 7(5). 219-224.

Green, John. 2009. Romance languages. In Bernard Comrie (ed.), The world's major languages, 2nd edn., 164-170. London \& New York: Routledge.

Gries, Stefan \& Stefanie Wulff. 2005. Do foreign language learners also have constructions? Evidence from priming, sorting, and corpora. Annual Review of Cognitive Linguistics 3. 182-200.

Holme, Randal. 2004. Mind, metaphors and language teaching. Basingstoke: Palgrave.

Holme, Randal. 2010. Construction grammars. Towards a pedagogical model. AILA Review 23. 115-133.

Holme, Randal. 2012. Cognitive linguistics and the second language class. TESOL Quarterly 46(1). 6-29.

Inegaki, Shunji. 2001. Motion verbs with goal PPs in the L2 acquisition of English and Japanese. Studies in Second Language Acquisition 23. 153-170.

Jamet, Marie-Cristine. 2009. Contact entre langues apparentées: les transfert négatifs et positifs d'apprenants italophones en français. Synergies Italie 5. 49-59.

Jarvis, Scott. 2012. The detection-based approach: An overview. In Scott Jarvis \& Scott Crosley (eds.), Approaching language transfer through text classification, 1-34. Bristol: Multilingual matters

Jarvis, Scott \& Anita Pavlenko. 2008. Crosslinguistic influence in language and cognition. New York: Routledge.

Kellerman, Eric. 1983. Now you see it, now you don't. In Susan Gass \& Larry Selinker (eds.), Language transfer in language learning, 112-134. Rowley: Newbury House.

Lakoff, George \& Mark Johnson. 1980. Metaphors we live by. Chicago: University of Chicago Press.

Landone, Elena. 2001. Consciousness raising e la traduzione per unità lessicali. In Antonella Cancellier \& Renata Londiero (eds.), Italiano e spagnolo a contatto, Atti del XIX convegno dell'A.I.S.P I., 141-150. Padova: Unipress.

Larrañaga, Pilar, Jeanine Treffers-Daller, Francois Tidball \& Mari Gil Ortega. 2012. L1 transfer in the acquisition of manner in Spanish by native speakers of English. International Journal of Bilingualism 16(1). 117-138. 
Lefebvre, Claire, Lydia White \& Christine Jordan. 2006. Introduction. In Claire Lefebvre, Lydia White \& Christine Jordan (eds.), L2 acquisition and creole genesis, 1-14. Amsterdam \& Philadelphia: John Benjamins.

Lemmens, Maarten. 2002. The semantic network of Dutch posture verbs. In John Newman (ed.), The linguistics of sitting, standing and lying, 103-139. Amsterdam \& Philadelphia: John Benjamins.

Lindstromberg, Seth \& Frank Boers. 2005. From movement to metaphor with manner-of-movement verbs. Applied Linguistics 26. 241-261.

Littlemore, Jeanette. 2011. Applying Cognitive Linguistics to second language learning and teaching. Basingstoke: Palgrave Macmillan.

Lysinger, Diana. 2015. The case for hidden meaning: An application of Cognitive Linguistics in the Russian classroom. In Kyoko Masuda, Carlee Arnett and Angela Labarca (eds.), Cognitive linguistics and sociocultural theory. Applications for second and foreign language teaching, 233-258. Berlin \& New York: Mouton de Gruyter.

Maiden, Martin \& Cecilia Robustelli. 2000. A reference grammar of Modern Italian. London: Arnold.

Morgana, Silvia \& Anna Zaffaroni. 2010. L'insegnamento dell'italiano L2 a ispanofoni. Aspetti e proposte didattiche. In Maria Vittoria Calvi, Giovanna Mapelli \& Milin Bonomi (eds.), Lingua, identità e immigrazione, 191-208. Milan: Franco Angeli.

Odlin, Terence. 1989. Language transfer: Cross-linguistic influence in language learning. Cambridge: Cambridge University Press.

Odlin, Terence. 2008. Conceptual transfer and meaning extension. In Peter Robinson \& Nick Ellis (eds.), Handbook of cognitive linguistics and second language acquisition, 306340. New York: Routledge.

Olbertz, Hella. 1998. Verbal periphrases in a functional grammar of Spanish. Berlin \& New York: Mouton de Gruyter.

Ringbom, Håkan. 2007. The importance of cross-linguistic similarity in foreign language learning: Comprehension, learning and production. Clevedon: Multilingual Matters.

Rosemeyer, Malte. In press. The development of iterative verbal periphrases in Romance. To appear in Linguistics.

Ruiz de Mendoza Ibáñes, Francisco. 2008. Cross-linguistic analysis, second language teaching and cognitive semantics: The case of Spanish diminutives and reflexive constructions. In Sabine De Knop \& Teun De Ryker (eds.), Cognitive approaches to pedagogical grammar: $A$ volume in honour or René Dirven, 37-66. Berlin \& New York: Mouton de Gruyter.

Salamoura, Angeliki \& John Williams. 2007. Processing verb argument structure across languages: Evidence for shared representations in the bilingual lexicon. Applied Psycholinguistics 28, 627-660.

Schmid, Stephan. 1994. L'italiano degli spagnoli. Milan: Franco Angeli.

Schmidt, Richard. 1995. Consciousness and foreign language learning: A tutorial on the role of attention and awareness in learning. In Richard Schmidt (ed.), Attention and awareness in foreign language learning, 1-63. Honolulu: University of Hawai'i.

Schwartz, Bonnie Dale. 1998. The second language instinct. Lingua 106. 133-160

Talé, Gilles Kuitche. 2013. Variazione diatopica del francese e didattica dell'italiano L2: i transfer negativi degli apprendenti camerunensi nell'italiano. Italiano LinguaDue 2. 79-95.

Tyler, Andrea. 2008. Cognitive linguistics and second language instruction. In Peter Robinson \& Nick Ellis (eds.), Handbook of cognitive linguistics and second language acquisition, 456488. New York: Routledge. 
Tyler, Andrea, Charles Mueller \& Vu Ho. 2011. Applying cognitive linguistics to learning the semantics of English to, for and at : An experimental investigation. VIAL 8. 181-205.

Valentini, Ada. 2007. La perifrasi andare a + infinito nell'italiano contemporaneo. Studi Italiani di Linguistica Teorica e Applicata XXXVI(2). 215-234.

Vietti, Alessandro. 2005. Come gli immigrati cambiano l'italiano. Milano: Franco Angeli.

Violi, Patrizia. 2012. How our bodies become us: Embodiment, semiosis and intersubjectivity. Journal of Cognitive Semiotics IV(1). 57-75.

Weger, Ullrich \& Jay Pratt. 2008. Time flies like an arrow: Space-time compatibility effects suggest a mental timeline. Psychonomic Bullettin \& Review 15(2). 426-430.

White, Lidia. 1991. Argument structure in second language acquisition. French Language Studies 1. 189-207.

Wong, Wynne. 2005. Input enhancement. Boston: McGraw-Hill.

Yin, Bin \& Elsi Kaiser. 2011. Chinese speakers' acquisition of telicity in English. In Gisela Granena, Joel Koeth, Sunyoung Lee-Ellis, Anna Lukyanchenko, Goretti Prieto Botana \& Elizabeth Rhoades (eds.), Selected proceedings of the 2010 second language research forum: Reconsidering SLA research, dimensions and directions, 182-198. Sommerville: Cascadilla Proceedings Project.

Zurlo, Francesco. 2009. Fenomeni d'interferenza nell'apprendimento dell'italiano da parte di parlanti spagnolo. Italiano LinguaDue 1. 
15

16

18

21

22

23

24

25

26

27

28

29

30

31

32

33

34

35

36

37

38

39

40 